\title{
前立腺高温度治療の効果発現メカニズムに関する基礎的研究
}

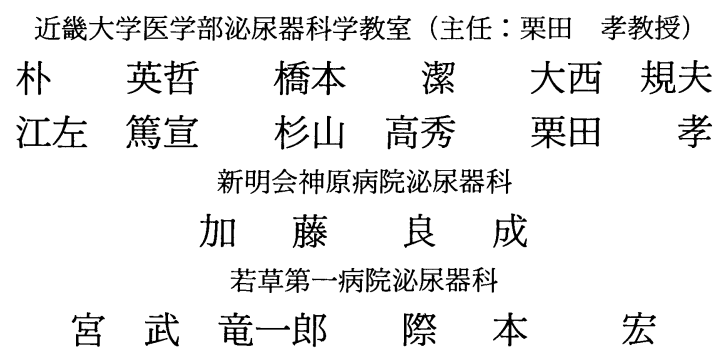

\section{HOW DOES THERMOTHERAPY EFFECTIVELY WORK ON BENIGN PROSTATIC HYPERPLASIA}

- An Experimental Study-

Young-Chol Park ${ }^{1)}$, Kiyoshi Hashimoto ${ }^{1}$, Norio Ohnishi ${ }^{1}$, Atsunobu Esa ${ }^{1}$, Takahide Sugiyama ${ }^{1)}$, Takashi Kurita ${ }^{1)}$, Yoshinari Katoh $^{2}$, Ryuichiro Miyatake ${ }^{3)}$ and Hiro Kiwamoto ${ }^{3)}$

${ }^{1)}$ Department of Urology, Kinki University School, of Medicine

(Director: Prof. T. Kurita)

${ }^{2}$ Department of Urology, Shinmeikai Kanbara Hospital

${ }^{3}$ Department of Urology, Wakakusa Daiichi Hospital

Isometric contractile force of rabbit prostatic tissue in response to electric field stimulation (EFS), $\mathrm{KCl}$, and phenylephrine were measured at incubation temperature of $37^{\circ} \mathrm{C}$, before and after thermal exposure to $42^{\circ} \mathrm{C}, 45^{\circ} \mathrm{C}, 48^{\circ} \mathrm{C}$ and $50^{\circ} \mathrm{C}$ for 30 minutes. The contractile force in response to $\mathrm{EFS}$ decreased after thermal exposure above $45^{\circ} \mathrm{C}$, and the contractile force in response to $\mathrm{KCl}$ or phenylephrine decreased after thermal exposure above $48^{\circ} \mathrm{C}$. All the contractile response abolished after thermal exposure to $50^{\circ} \mathrm{C}$. The results indicate that the nerve is more hearsensitive than the smooth muscle in the prostate. Histological examination revealed shrinkage of cell body and dark stainig of nuclear chromatin of the smooth muscle cells after thermal exposure above $48^{\circ} \mathrm{C}$. The same histological change of the smooth muscle as well as degenerative change of the nerve cells was observed on the prostate $3 \sim 7$ months after clinical thermotherapy. From these results, it is suggested that clinical effect of thermotherapy is brought about from both neural and muscular damage of the prostate. Since the least temperature to cause an irreversible tissue damage ranges from $48^{\circ} \mathrm{C}$ through $50^{\circ} \mathrm{C}$, we believe it is ideal to heat the prostate around $50^{\circ} \mathrm{C}$ to obtain a good clinical effect of thermotherapy on benign prostatic hyperplasia as a minimum invasive treatmant.

Key words: prostate, thermotherapy, heat sensitivity

要旨：前立腺平滑筋の収縮性が高温度被曝によりどのような影響を受けるかを in vitro で検討し, 高温 度治療の効果発現メカニズムについて考察した. 雄家鬼の摘出前立腺切片をマグヌス管内に懸垂し, 経

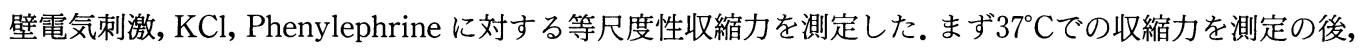
$42^{\circ} \mathrm{C}, 45^{\circ} \mathrm{C}, 48^{\circ} \mathrm{C}, 50^{\circ} \mathrm{C}$ ぞれぞれ 30 分間灌流加温し, 再び $37^{\circ} \mathrm{C} し て 30$ 分間冷却の後, 刺激に対する

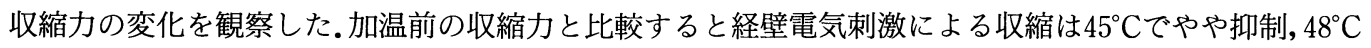

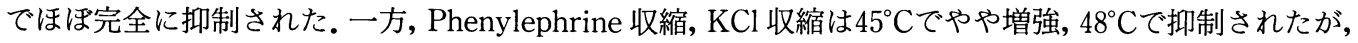
その抑制率は, Phenirephrine 収縮で高かった.いずれの収縮も $50^{\circ} \mathrm{Cで}$ 完全に抑制された. 組織学的変化 
をみると, $48^{\circ} \mathrm{C}$ 加温後には平滑筋細胞の萎縮や核の濃縮が観察された. 臨床の高温度治療 $3 \sim 7$ 力後 の前立腺標本においても同様の平滑筋変性のほか, 神経細胞の退行変性が観察された. 以上の結果より,

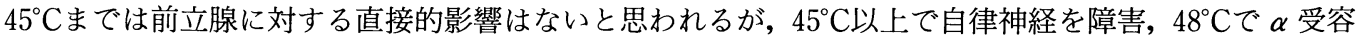
体ないしそれに関連した収縮機構を障害， $50^{\circ} \mathrm{C} て ゙$ 細胞膜の分極状態が破壊され，細胞死に至ると思われ た．臨床の治療成績が前立腺の縮小を伴わないことから，その効果は熱壊死一吸収による形態的改善で はなく, 自律神経, 感覚神経の障害や細胞収縮機構の破壊による機能的変化に基づくものであろうと考 えられた。

キーワード：前立腺，高温度治療，温度感受性

\section{緒 言}

前立腺肥大症に対するマイクロ波を用いた局所加温

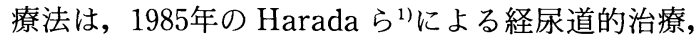
Yerushalmi $ら^{2)}$ による経直腸的治療の報告以来, 装置 の改良と普及の努力がなされ，現在では世界的な規模 で臨床応用されている。.また，従来の局所加温の意味 での hyperthermia（温熱療法：組織内温度 $45^{\circ} \mathrm{C}$ 末満） から，高温度加熱による組織壊死を目指した thermotherapy（高温度治療：組織内温度 $45^{\circ} \mathrm{C}$ 以上）へと 治療法の幅も広くなっている ${ }^{3)}$. 高温度治療に関して はすでに世界で 1 万例以上の治療が行われ，いくつか の優れた成績が報告されている(4) 6). しかし，いずれに おいても前立腺の縮小は伴わず，頻尿を中心とした自 覚症状の改善が強調されている，仮に高温度治療の効 果が前立腺組織の壊死，吸収に基づくものであれば， ある程度の前立腺容積の減少が観察されるべきであろ うが，われわれの施設での治療経験からも，臨床症状 の改善に一致した前立腺の縮小はみられず，病理所見 においても前立腺組織の壊死像は極めて限局的なもの であった，以上のことから，われわれは高温度治療の 効果発現のメカニズムには前立腺の熱壊死一吸収によ る形態的改善以外の作用が絡んでいるのではないかと 考えている．前立腺の高温度治療は今後さらに高エネ ルギー化し，広範囲な組織脱落をもたらす方向に向 かっているようであるが，このような方向が妥当なも のであるかどうかを検証する意味でも，本治療法の効 果のメカニズムに関する基礎的検討が必要と考え，前 立腺平滑筋とその収縮に関与する神経の温度感受性に ついて, 薬理学的ならびに組織学的検討を行ったので 報告する。

\section{対象および方法}

\section{1. 収縮実験}

雄家鬼13羽を脱血屠殺して前立腺を摘出し，長軸方 向に切断して $2 \mathrm{~mm} \times 10 \mathrm{~mm}$ の短冊状切片を作成した. これを容積 $5 \mathrm{ml}$ のマグヌス管内に $0.5 \mathrm{~g}$ の張力を加え
て懸垂し $95 \% \mathrm{O}_{2}+5 \% \mathrm{CO}_{2}$ で飽和した Krebs 液中で $37^{\circ} \mathrm{C}, 1$ 時間静置した後, 経壁電気刺激, $\mathrm{KCl}$, phenylephrine に対する等尺性収縮力を測定した. まず $37^{\circ} \mathrm{Cで}$ 実験し, 次に高温度灌流 $\left(42^{\circ} \mathrm{C}, 45^{\circ} \mathrm{C}, 48^{\circ} \mathrm{C}, 50^{\circ} \mathrm{C}\right)$ を 30 分間行い，再び $37^{\circ} \mathrm{C}$ に切り替えて 30 分間冷却して から同じ収縮実験を行い，高温度被曝による収縮力の 変化を観察した (Fig. 1)。なお，1検体では 2 つの温 度域（例えば $42^{\circ} \mathrm{C} \rightarrow 48^{\circ} \mathrm{C}$ ）までの検討にとどめた.

\section{2. 組織学的検討}

収縮実験に使用した標本は最終被曝温度域ごとに $10 \%$ ホルマリンおよび $2 \%$ \%゙ルタールアルデヒドに浸 積固定し, それぞれ H-E 染色による光顕, および鉛染 色による透過型電顕で，おもに平滑筋細胞の変化につ いて検討した. また, プロスタトロン®による高温度治 療 (TUMT) 後 3 カ月の症例 A (N.M. : 74歳)におけ

Fig. 1 Schema of experiments. The isometric contaction force was measured under incubation temperature of $37^{\circ} \mathrm{C}$ before and after thermal exposure.
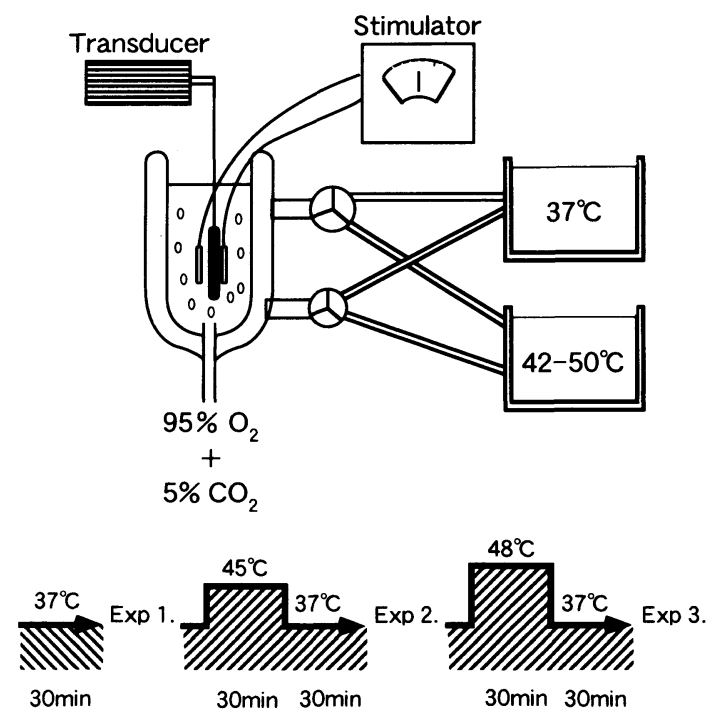
る前立腺針生検標本と, 治療後 7 力月の症例 B(T.T : 82歳）の前立腺核出術標本を H-E 染色抒よび S-100蛋 白免疫染色で観察した。

\section{結 果}

\section{1. 収縮実験}

$37^{\circ} \mathrm{C}$ 灌流において，経壁刺激は $10 \mathrm{~Hz} ， 30 \mathrm{~V} ， 15$ 秒間 で最大収縮が得られ，この収縮は tetrodotoxin $10^{-4} \mathrm{M}$ の投与で完全に抑制された。よって経壁刺激による収 縮は前立腺内を走行する神経の興奮による収縮と判断 し, 以後の実験は同条件で 5 分以上の間隔を開けて繰 り返し刺激した。

$\mathrm{KCl}$ による収縮は $10 \mathrm{mM}$ より用量依存的に増強し， 90mM でほほ最大収縮に達した。また, phenylephrine による収縮は $10^{-7} \mathrm{M}$ より用量依存的に增強し， $10^{-4} \mathrm{M}$ で最大収縮に達した。 以上の結果より, 以後の実験は $\mathrm{KCl} 90 \mathrm{mM}$, phenylephrine $10^{-4} \mathrm{M}$ の最大収縮で比較 した.つぎに $45^{\circ} \mathrm{C}, 48^{\circ} \mathrm{C}$ 各高温度被曝後の $\mathrm{KCl}$ およ び phenylephrine の用量作用曲線を $37^{\circ} \mathrm{C}$ ものと比較 すると, $45^{\circ} \mathrm{C}$ 加温後では最大収縮力がいずれも増強す る傾向が， $48^{\circ} \mathrm{C}$ 加温後ではいずれも減弱する傾向が観 察された。また, $48^{\circ} \mathrm{C}$ 加温後では $\mathrm{KCl}$, phenylephrine
収縮とも曲線の右方偏位がみられた（Fig. 2)。

収縮実験の典型例を Fig. 3 に示した. $45^{\circ} \mathrm{C}$ 加温後に は経壁刺激の収縮は影響を受けず， $\mathrm{KCl} や$ phenylephrine の収縮はやや増強した. $48^{\circ} \mathrm{C}$ 加温後では経壁刺 激の収縮は完全に消失し， $\mathrm{KCl}$ や phenylephrine の収 縮は逆に減弱した。さらに $50^{\circ} \mathrm{C}$ 加温後ではどの刺激に 対してもまったく収縮反応を起こさなくなった。

経壁刺激の収縮と phenylephrine 収縮に対する各温 度被曝の影響を， $37^{\circ} \mathrm{C}$ 対照に扔ける収縮張力の百分率

Fig. 2 Dose response curve for $\mathrm{KCl}$ and phenylephrine under $37^{\circ} \mathrm{C}$, before and after incubation at $45^{\circ} \mathrm{C}$ or $48^{\circ} \mathrm{C}$.
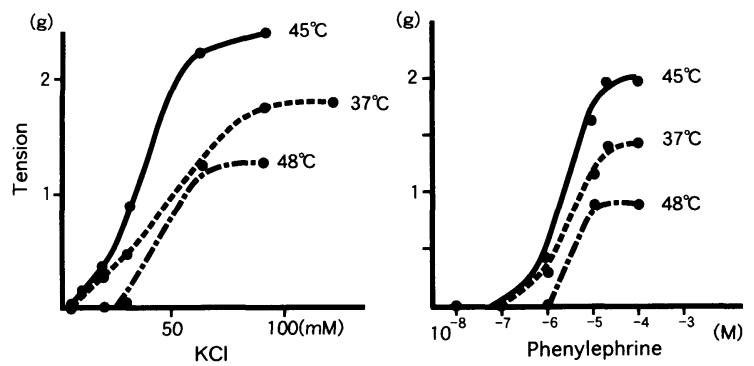

Fig. 3 Actual record of the experiment. EFS induced contraction was completely suppressed while $\mathrm{KCl}$ or phenylephrine induced contraction was partially suppressed after incubation at $48^{\circ} \mathrm{C}$. No contraction was induced after incubation at $50^{\circ} \mathrm{C}$.

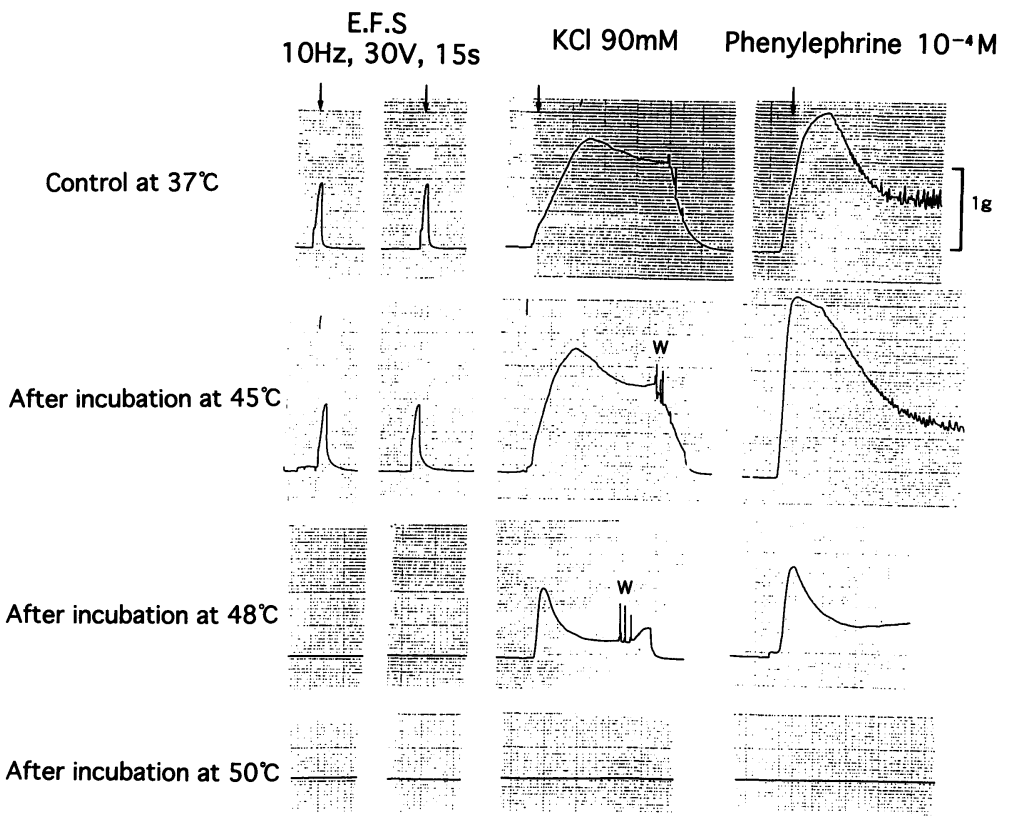


Fig. 4 Relative contactile force induced by EFS and phenylephrine after thermal exposure.

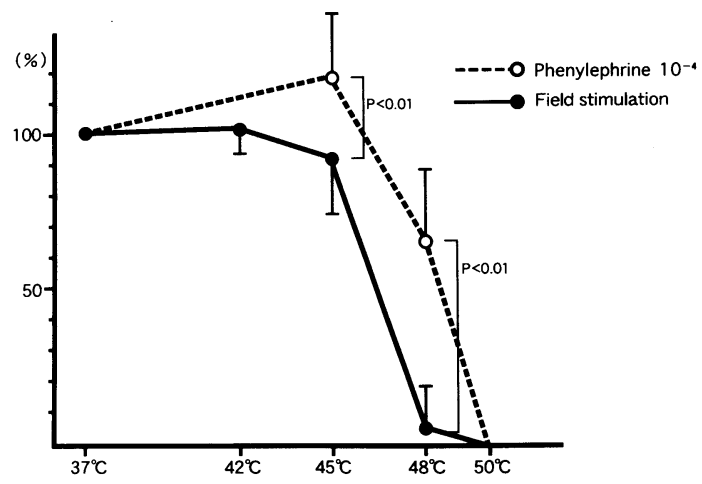

Fig. 5 Inhibitory effect of thermal exposure to contractions induced by EFS, phenylephrine and $\mathrm{KCl}$.

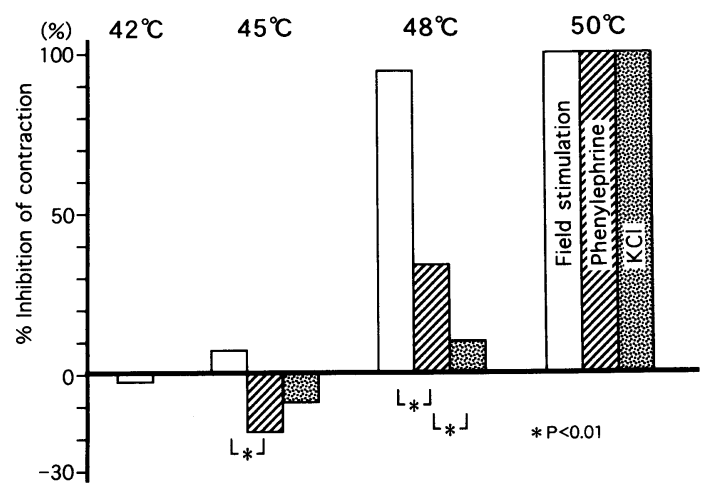

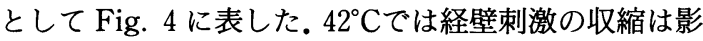
響を受けないが, $45^{\circ} \mathrm{C}$ 加温後ではやや減弱した。一方, phenylephrine 収縮はこの温度域ではむしろ収縮は増 強した. $48^{\circ} \mathrm{C}$ 加温後では経壁刺激の収縮は平均 $5.8 \%$ し か残存せずほぼ消失したのに対し, phenylephrine 収 縮は $65.8 \%$ 残存し,有意に温度抵抗性が高かった. $50^{\circ} \mathrm{C}$ 加温後ではいずれの刺激に対してもまったく反応性は 消失した。

$37^{\circ} \mathrm{C}$ での収縮張力に対する高温度被曝後の抑制率を Fig. 5 に示した。 $\mathrm{KCl}$ 収縮は経壁刺激や phenylephrine 収縮に比して有意に温度抵抗性が高く, $48^{\circ} \mathrm{C}$ 加 温後も平均 $10 \%$ 抑制されたのみであったが, $50^{\circ} \mathrm{C}$ 加温 後はこの収縮も完全に消失した。

2. 組織学的検討

最終被曝温度地域毎に H-E 染色標本を観察すると, $45^{\circ} \mathrm{C}$ では前立腺平滑筋に明らかな形態変化はみられ

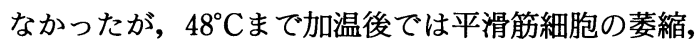
細胞質の濃染, 核の萎縮, 濃縮, 細胞間吵の拡大が観 察された.さらに $50^{\circ} \mathrm{C}$ 加温後にも同様の変化が観察さ れたが, その程度は $48^{\circ} \mathrm{C}$ 加温後よりも高度であった (Fig. 6).

電子顕微鏡で平滑筋の微細形態をみると, $45^{\circ} \mathrm{Cまで}$ は細胞膜, 筋原繊維に明らかな変化は観察されなかっ たが, $48^{\circ} \mathrm{C}$ 加温後では細胞膜の不鮮明化や細胞間隙の 拡大の他, 細胞内において筋原㵶維の不均質化が観察 された (Fig. 7). 50 $0^{\circ} \mathrm{C}$ 加温後も同様の変化が観察され た。

TUMT 3 力月後の症例 A の前立腺針生検標本 (HE 染色) をみると, 実験標本で $48^{\circ} \mathrm{C}$ 加温後に見られ た所見と同様の所見が観察された。ただし，このよう な変化は前立腺全体に及ぶものではなく，尿道近位側 に限局した所見であった（Fig. 8).

TUMT 7 力月後の症例 B の摘出前立腺を観察する と実験標本でみられた平滑筋の変性所見は尿道近位側 を中心に半径約 $2 \mathrm{~cm}$ の範囲で観察された．さらに，S100 蛋白免疫染色で神経を染色したところ,神経瀻維内 の空胞形成は尿道側より約 $3 \mathrm{~cm}$ の深さまで観察され た (Fig. 9).

\section{考察}

前立腺肥大症に対する温熱治療は Devonec らによ り $45^{\circ} \mathrm{C}$ 以下の hyperthermia (温熱療法) と, $45^{\circ} \mathrm{C}$ 以上 で組織壊死を目指した thermotherapy（高温度治療） に分類されている3). しかしながら前立腺組織は腺上 皮，平滑筋，神経の混合した組織であり，それぞれの

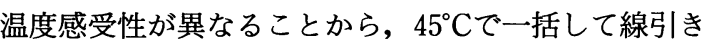
をすることには問題があると思われる。 また，本来低 侵襲性を目指して開発された温熱治療がいたずらに高 温度に向かい, 不必要な組織障害をもたらすことも懸 念され，治療効果を得るに必要十分な至適温度域の決 定が必要と思われる。

今回の研究において, $45^{\circ} \mathrm{C}$ 以下では平滑筋や神経に 対する直接効果は薬理学的にも組織学的にも観察され

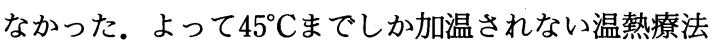
では前立腺組織に対する直接効果は期待できないと考 えられた。その臨床効果は, Montorsi らてが指摘する ように血管の拡張や増生による二次的効果であろうと 思われる.一方， $45^{\circ} \mathrm{C}$ 以上の温度域に関しては組織の

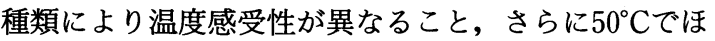
ほ致死的な細胞障害を与えることが判明した．神経が 最も低温度で障害を受け, $48^{\circ} \mathrm{C}$ 加温後には神経刺激に 
Fig. 6 Histological change (HE stain) of the rabbit prostatic tissue before (left) and after thermal exposure at $48^{\circ} \mathrm{C}$ (right).

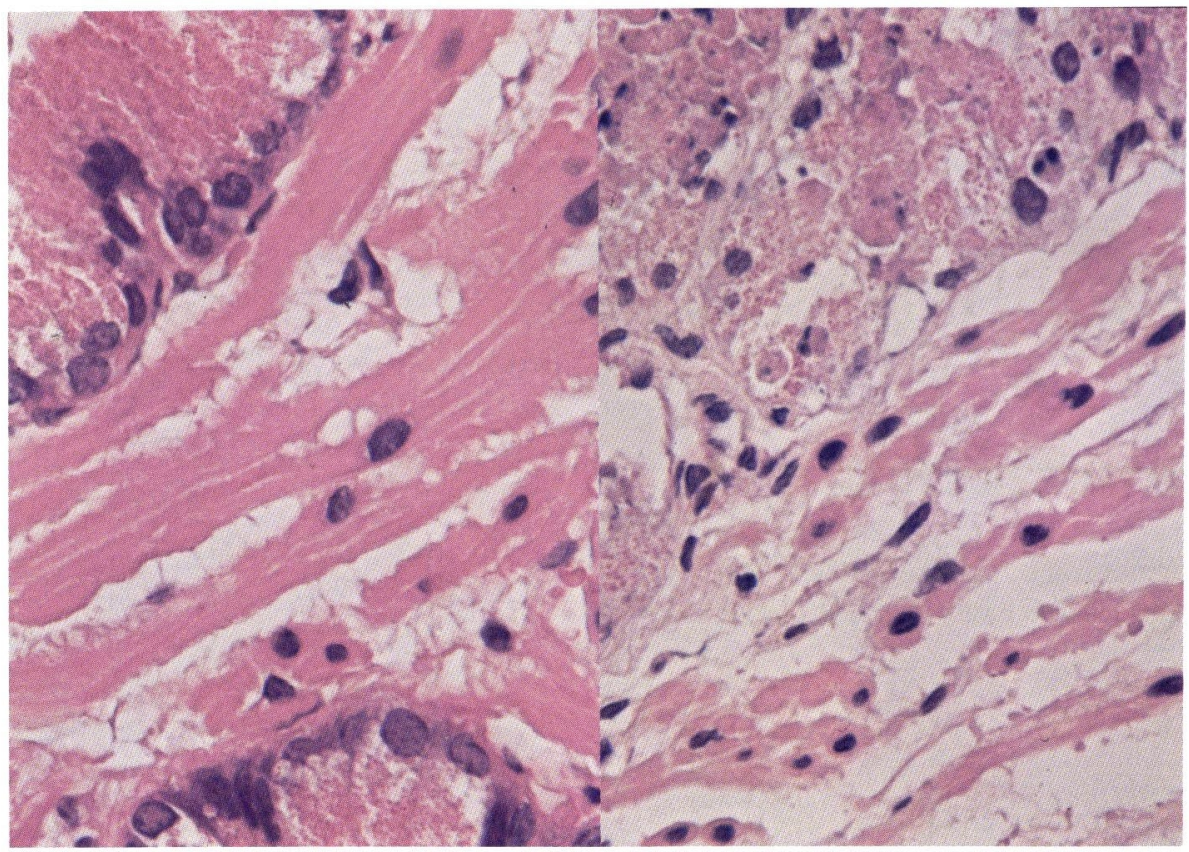

Fig. 7 Electron microscopic appearance of the rabbit prostatic tissue after thermal exposure at $45^{\circ} \mathrm{C}$ (left) and at $48^{\circ} \mathrm{C}$ (right).

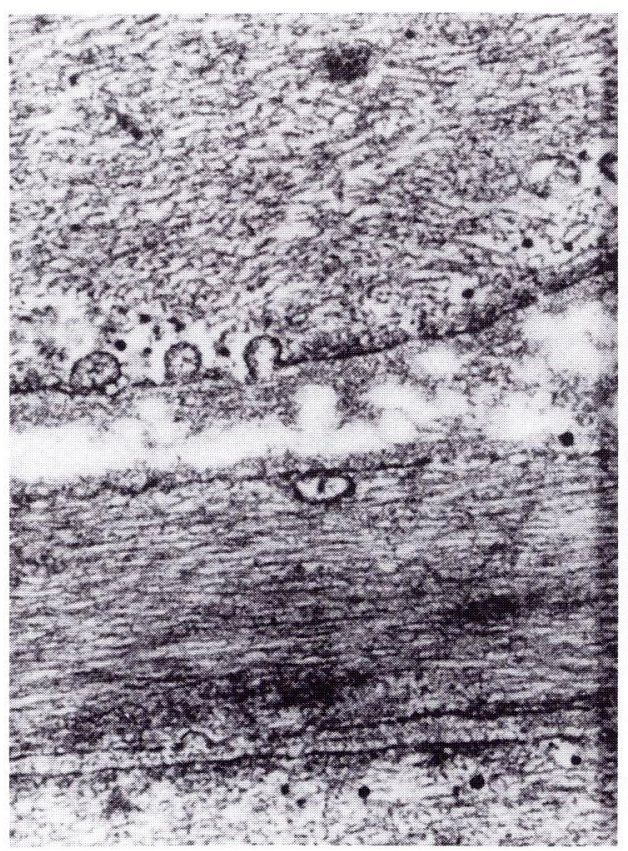

$\times 40,000 \quad 45^{\circ} \mathrm{C}$

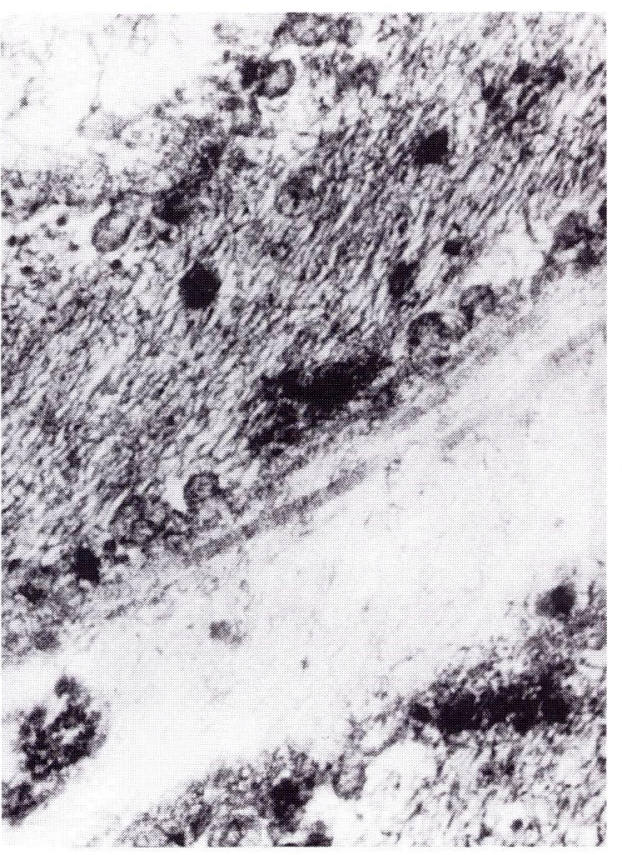

$\times 40,000 \quad 48^{\circ} \mathrm{C}$ 
Fig. $8 \mathrm{HE}$ stain of human prostatic tissue 3 months after TUMT shows a same histological change as observed in rabbit prostatic tissue after thermal exposure at $48^{\circ} \mathrm{C}$. (Fig. 6 right).

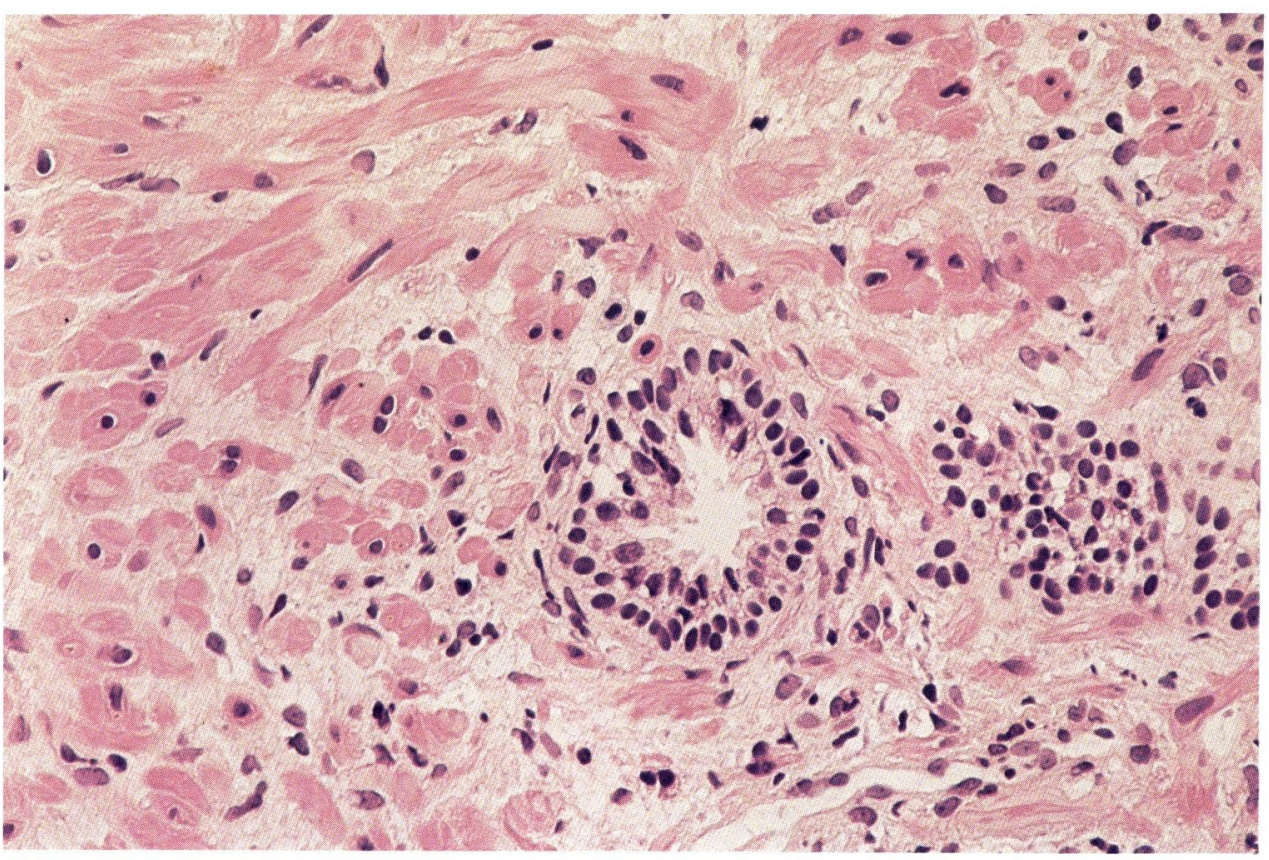

Fig. 9 Immunohistochemical stain with anti-S 100 protein monoclonal antibody shows vacuolar degeneration of the nerve fibers in human prostatic tissue 7 months after TUMT.

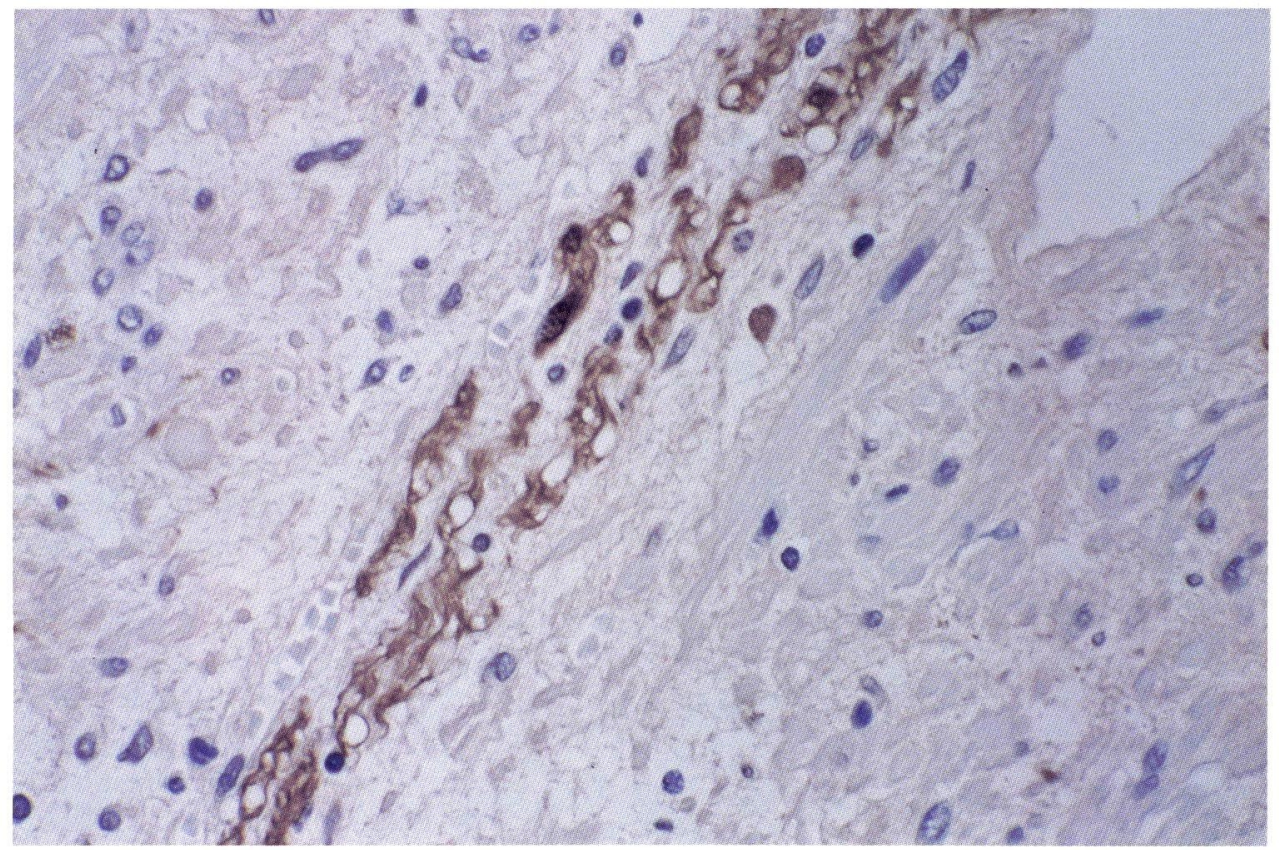


よる収縮はほぼ完全に抑制されるのに対し, phenylephrine 収縮に代表される $\alpha_{1}$ 受容体に制御された収縮 や, $\mathrm{KCl}$ 収縮に代表される膜電位依存性収縮は比較的

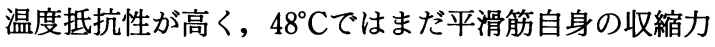
は保たれており組織障害は不十分と考えられた。さら に $50^{\circ} \mathrm{C}$ ま加温した後では受容体に制御された収縮も 膜電位依存性収縮も完全に消失し, 平滑筋細胞の完全 な機能喪失がもたらされた。組織学的には， $48^{\circ} \mathrm{C}$ 以上 で細胞膜の破壊のみならず細胞内の核や筋原織維の変 性が同時に観察された。これは薬理実験でみられた熱 による神経や平滑筋の機能喪失が， $\alpha$ 受容体の変性と いった選択的, 可逆的変化ではなく, 細胞全体の非可 逆的変化であることを裏づけるものである. 以上の検 討より, 前立腺の高温度治療は $50^{\circ} \mathrm{C}$ 必要かつ十分な 温度条件であると考えられる。

前立腺肥大症は病理学的には平滑筋の増生といわ れ, その症状発現には腺腫の大きさや形態といった解 剖学的閉塞の他, 交感神経 $\alpha$ 受容体の増加による機能 的閉塞が関与していることはよく知られている ${ }^{819)}$. 今 回の研究結果を踏まえた上で, 臨床の高温度治療の成 績が中葉肥大などの解剖学的閉塞が強い症例より両葉 肥大において効果が高いこと, 治療後に前立腺の縮小 がみられないことを考えあわせると, 高温度治療後に おける排尿困難の改善や残尿の減少は, 前立腺部尿道 の形態改善によるものというょりは, 前立腺平滑筋自 律収縮の抑制や交感神経の遮断による機能的尿路閉塞 の軽減によるものと解釈することができる.

さらに高温度治療の特徵として膀胱刺激症状の改善 が著しいと言われている．これは尿路閉塞の軽減によ る二次的効果とも考えられるが，今回の実験で神経の 機能障害が $48^{\circ} \mathrm{C}$ という比較的低温度域で起こること, TUMT 治療後の摘出標本で神経繊維の変性が比較的 広範囲に認められたことより, 著者らは尿道からの求 心性神経の障害に基づく麻酔样作用がもたらす効果の 可能性が高いと考えている.Chalfin らは前立腺肥大症 に伴う排尿筋の不随意収縮が前立腺内への局麻剂の注 入により消失することを(10), Yokoyama らは尿道粘膜 麻酔により前立腺肥大症に伴う排尿筋反射六進が抑制 されることから, 前立腺肥大症に伴う不随意収縮には 前立腺部尿道からの求心性インパルスが関与している 可能性を示唆している ${ }^{11}$. 前立腺の局所加温が求心性 神経の障害をもたらすのであれば，その麻酔様作用が 膀胱の不随意収縮を抑制し, 膀胱刺激症状を解消して いる可能性が考えられる。
以上の研究結果と非侵襲的外来治療という利点を生 かし, 今後の前立腺高温度治療の向かうべき方向性を 考察すると，その final gold はむしろ薬物療法のそれ に近く, volume reduction を目指す外科的治療のそれ とは自ずから異なると思われる.こういった意味では, 狭い範囲に高エネルギーを照射して前立腺組織の性急 な脱落を期待するのではなく, 前立腺全体が万遍なく $50^{\circ} \mathrm{C}$ 程度に加温され, より広い範囲の神経と前立腺平 滑筋が機能障害を起こす治療プログラムの作成が期待 される.

稿を終えるにあたり，本研究遂行に際して貴重な御助言 を賜りました本学薬理学教室梶本禮義助教授に感謝致しま す. なお, 本研究の要旨は第 7 回日本 Endourology-ESWL 学会総会および, 第82回日本泌尿器科学会総会において発 表した。

\section{文 献}

1) Harada, T., Nishizawa, O., Etori, K., Noto, H., Kumazaki, T. and Tsuchida, S.: Microwave surgical treatment of disease of prostate. Urology, 26, 572-576, 1985.

2) Yerushalmi, A., Fishelovitz, Y., Singer, D., Reiner, I., Arielly, J., Abramovici, Y., Katsnelson, R., Levy, E. and Shani, A.: Localized deep microwave hyperthermia in the treatment of poor operative risk patients with benign prostatic hyperplasia. J. Urol., 133, 873-876, 1985.

3) Devonec, M., Berger, N. and Perrin, P.: Transurethal microwave heating of the prostate-Or from hyperthermia to thermotherapy. J. Endourol., 5, 129-135, 1991.

4) Carter, S., Patel, A., Reddy, P., Royer, P. and Ramsay, J.: Single session transurethral microwave thermotherapy for treatment of benign prostatic obstruction. J. Endourol., 5, 137-144, 1991.

5）福庭雅洋, 本間之夫, 阿曾佳郎：前立腺肥大症に対 する経尿道的単回高温度治療の治療成績. 日泌尿 会誌, 83，1410-1416, 1992.

6）馬場志郎, 大東貴志, 桶 政昭, 出口修宏, 実川正 道, 畠 亮, 田崎 寛: 経尿道式高温度治療法に よる前立腺肥大症の単回治療成績. 日泌尿会誌, 82, 1916-1923, 1991.

7) Montorsi, F., Guazzoni, G., Colombo,R., Bulfamante, G., Galli, L., Matozzo, V., Consonni, P. and Rigatti, P.: Transrectal hyperthermiainduced histological and ultrastructural changes of human benign prostatic hyperplasia tissue. Eur. Urol., 22, 74-78, 1992. 
8）朴 英哲：前立腺肥大症における交感神経系の関 与について一神経性調節と体液性調節. 日泌尿会 誌, 79, 203-213，1988.

9) Furuya, S., Kumamoto, Y., Yokoyama, E., Tsukamoto, T., Izumi, T. and Abiko, Y.: Alpha adrenergic activity and urethral pressure in prostatic zone in benign prostatic hypertrophy. J. Urol., 128, 836-839, 1982.

10) Chalfin, S.A. and Bradley, W.E. : The etiology of detrusor hyperreflexia in patients with infravesical obstruction. J. Urol., 127, 938-942, 1982.

11) Yokoyama, O., Nagano, K., Kawaguchi, K., Ueki, O. and Ohkawa, M.: The influence of prostatic urethal anesthesia in overactive detrusor in patients with benign prostatic hyperplasia. J. Urol., 151, 1554-1556, 1994.

（1994年12月12日受付，1995年3月27日受理） 